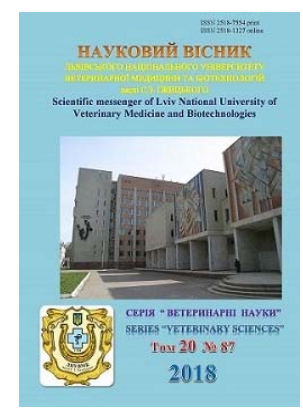

\author{
Науковий вісник Дьвівського національного університету \\ ветеринарної медицини та біотехнологій імені С.З. Гжицького
}

\author{
Scientific Messenger of Lviv National University \\ of Veterinary Medicine and Biotechnologies
}

UDC 576.8:58

\title{
Antimicrobic activity concept of water extract of plants Galega orientalis (Lam.)
}

\author{
L.M. Darmohray ${ }^{1}$, B.V. Gutyj ${ }^{1}$, O.O. Darmohray ${ }^{2}$ \\ ${ }^{1}$ Stepan Gzhytskyi National University of Veterinary Medicine and Biotechnologies Lviv, Ukraine \\ ${ }^{2}$ Lviv Secondary School № 2, Lviv, Ukraine
}

Article info

Received 28.02.2018

Received in revised form 29.03.2018

Accepted 03.04.2018

Stepan Gzhytskyi National University of Veterinary Medicine and Biotechnologies Lviv, Pekarska Str., 50, Lviv, 79010, Ukraine.

Tel.:+38-097-561-52-30

E-mail:murolyb@ukr.net

Lviv Secondary School №2, Volodymyra Velykogo Str., 55A, Lviv, 79053, Ukraine.

E-mail:lvivschool2@ukr.net
Darmohray, L.M., Gutyj, B.V., \& Darmohray, O.O. (2018). Antimicrobic activity concept of water extract of plants Galega orientalis (Lam.). Scientific Messenger of Lviv National University of Veterinary Medicine and Biotechnologies. 20(87), 122-125. doi: 10.15421/nvlvet8724

It was first conducted testing on antimicrobial activity of Galega orientalis (La) on the growth pure cultural of bacteria gram positive (Micrococcus luteus), gram negative (Escherichia coli XL1, DH5) and yeasts (Saccharomyces cerevisiae W303). The material for the study was dried vegetative mass Galega orientalis (Lam) in the phase of budding and early flowering. In experiment used medium «Endo» for gram negative, medium LB for gram positive and gram negative, and suslo agar for yeasts. As a result of the experiment was revealed that $20 \%$ concentration of aqueous extract of this plant had inhibitory effects on the growth of pure cultures of bacteria and yeast. Antimicrobial effect of this drug on the growth of gramnegative bacteria (Escherichia coli XL1, DH5) were within 20.0-30.0\% $(P<0.001)$, gram-positive bacteria (M. Luteus) $-12.0 \%(P<0.05)$ and yeast (S. cerevisiae W303) $-30.5 \%(P<0.01)$ compared with control. It should be noted that in all cases the addition of the drug Galega orientalis (La) did not alter the morphology of colonies (colony size) test strains. The questions of search the new antimicrobial agents, include natural origin, is very actual during last years. Increasing microbiological pure of eating products, feed grinders, veterinarian preparations are one of the urgent task of Scientifics and industrials. It has proved the influence of different concentrations of aqueous extract of this culture on the growth of pure cultures of gram-positive and gram-negative bacteria and yeast. Install antimicrobial influence 20-30\% concentrations of preparation on the bacteries growth (Escherichia coli XL1, DH5). Bacterial action of preparation on the bacteries (Micrococcus luteus) and yeasts (Saccharomyces cerevisiae W303) were lower. It was described the prospects for further investigation of this problem. It has proved possible relationship between the antimicrobial activity of the extract of this plant and bloating of the rumen in ruminants.

Keys word: Galega orientalis (Lam), water extract, Escherichia coli, Micrococcus luteus, Saccharomyces cerevisiae.

\section{Концепція антимікробної активності водного екстракту рослини Galega orientalis (Lam)}

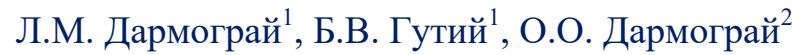 \\ ${ }^{1}$ Львівський національний університет ветеринарної медицини та біотехнологій імені С.3. Гэницкого, \\ м. Львів, Украӥна \\ ${ }^{2}$ Львівська середня загальноосвітня школа № 2, м. Львів, Україна
}

Bперше в умовах in vitro проведено тестування можливої антимікробної активності водного екстракту Galega огіеntalis (Lam) на ріст чистих культур бактерій грам-позитивних (Micrococcus luteus), грам-негативних (Escherichia coli XL1, DH5) ma дріжджів (Saccharomyces cerevisiae W303). Матеріалом для дослідження слугувала висушена вегетативна маса Galega огіепtаlis (Lam) у фазі бутонізаиії і початку ивітіння. В експериментах використовували середовище «Ендо» для росту грам-негативних бактерій і середовище LB на якому виростають як грам-позитивні, так і грам-негативні бактерії, а також сусло-агар для дріжджів. У результаті експерименту встановлено, щзо 20\% концентрація водного екстракту даної рослини має інгібуючий вплив на ріст чистих культур бактерій та дріжджів. Антимікробний ефект даного препарату на ріст грам-негативних бактерій (Escherichia coli XL1, DH5) був у межах 20,0-30,0\% (P<0,001), грам-позитивних бактерій (M. Lutеиs) - 12,0\% (P < 0,05) та дріжджів (S. cеrevisiae W303) - 30,5\% (P < 0,01) порівняно з контролем. Слід відзначити, щзо у всіх випадках додавання препарату 
Galega orientalis (Lam) не змінював морфологію колоній (розмір колоній) тестових штамів. Питання пошуків нових антимікробних агентів, у тому числі природного походження, стає в останні роки все більш актуальним, оскільки підвищення мікробіологічної чистоти продуктів харчування, кормових добавок та ветеринарних препаратів на сьогоднішній день є одним із першочергових завдань науковців і виробників про, що вказують публікачій вітчизняних та зарубіжних вчених. Внаслідок проведених експериментальних досліджень з'ясовано вплив різних конщентрацій водного екстракту даної культури на ріст чистих культур грампозитивних і грам-негативних бактерій і дріжджів. Встановлено інгібуючий вплив препарату в межах 20-30\% на ріст бактерій штаму Escherichia coli XL1, DH5. Антимікробна дія дослідженого препарату на бактерії штаму Містососсиs lитеиs та дріжджі Saccharomyces cerevisiae W303 була нижчою. Обгрунтовано можливий взаємозв 'язок між антимікробною активністю екстракту цієї рослини та виникнення тимпанї у жуйних. Окреслено перспективи подальиих досліджень даної проблеми.

Ключові слова: Galega orientalis (La), водний екстракт, Escherichia coli, Micrococcus luteus, Saccharomyces cerevisiae.

Вступ

У науковому світі триває пошук нових і більш стабільно-сильних компонентів антимікробної дії природного походження на противагу існуючим синтетичним антибіотикам та підвищення мікробіологічної чистоти продуктів харчування, кормових добавок. Згідно публікації вітчизняних і зарубіжних авторів $€$ значна зацікавленість щодо вивчення антимікробної активності нетрадиційних, але перспективних агрокультур, однією 3 яких є Galega orientalis (Lam), яка належить до багаторічних бобових рослин (Khan et al., 2001; Cwalina-Ambroziak and Koc, 2005; Sibanda and Okoh, 2008; Darmohray, 2009; Egamberdieva et al., 2010; Symanowicz et al., 2015; Darmohray et al., 2017).

Використання природних речовин, які мають антимікробну дію, $є$ досить важливим 3 огляду на декілька моментів: у мікроорганізмів немає резистентності до них і можливе тривале застосування; не викликають шкідливої (негативної) дії на організм людини і тварини; завдяки своїй гальмівній дії на небажану мікрофлору можуть бути застосовані у харчовій промисловості, оскільки при виробництві харчових продуктів не дозволяється використовувати синтетичні антибіотики (за винятком пептидного антибіотику нізину) (Hrinkevich, 1983; Darmohray, 2010; Egamberdieva et al., 2010; Sen and Batra, 2012; Darmohray and Vlizlo, 2015; Darmohray and Gonchar, 2015; Darmohray, 2016).

Метою дослідження було тестування можливої антимікробної дії водних екстрактів Galega orientalis (Lam) на моделі чистих культур бактерій грампозитивних (Micrococcus luteus), грам-негативних (Escherichia coli XL1, DH5) та дріжджів (Saccharomyces cerevisiae W303).

\section{Матеріал та методи досліджень}

Матеріалом для дослідження слугувала висушена вегетативна маса даної рослини у фазі бутонізації $\mathrm{i}$ початку цвітіння. В експериментах використовували середовище «Ендо» для росту грам-негативних бактерій i середовище LB, на якому виростають як грампозитивні, так і грам-негативні бактерії, а також сусло-агар для дріжджів.

Готували $10 \%$ і $20 \%$ витяжку препарату (висушеної трави) при кип'ятінні і настоюванні упродовж 10 15 год. Екстракти стерилізували холодною фільтрацією. Після цього на поверхню чашки із агаризованим середовищем наносили по 0,1 мл досліджуваного екстракту і засівали іiі газоном відповідною культу- рою. Всі експерименти проводили на 10 контрольних i 10 дослідних чашках. Аналізували появу колоній на 2-3 добу після засіву при $+30{ }^{\circ} \mathrm{C}$ (дріжджі) і першу добу при $+35-37{ }^{\circ} \mathrm{C}$ (бактеріі), порівнюючи дослідні варіанти 3 контролем (без введення екстракту).

Отримані в експериментах цифрові дані оброблені біометрично із використанням комп'ютерних програм в середовищі MS Office 2003 програма «Statistica». Результати середніх значень вважали статистично вірогідними * $-\mathrm{P}<0,05,{ }^{* *}-\mathrm{P}<0,01,{ }^{* * *}-\mathrm{P}<0,001$.

\section{Результати та іх обговорення}

За період експерименту було помічено, що препарат досліджуваної культури у концентрації 10\% (у перерахунку на вихідну масу висушеної рослини) практично не впливав на ріст грам-позитивних і грамнегативних бактерій, а також дріжджів. Внаслідок збільшення концентрації водного екстракту до $20 \%$ встановлено, що на чашках Петрі контрольної групи виростало $540 \pm 15$ колоній бактерій $E$. coli штаму $X L 1$, а у дослідній із додаванням $20 \%$-го препарату Galega orientalis (La) налічувалось на 110 колоній менше. Отже, спостерігалося пригнічення росту даних бактерій на 20,0\% (P < 0,001) порівняно 3 контрольними чашками. Міжгрупова різниця за даним показником статистично вірогідна. Результати тестування антимікробної активності досліджуваного препарату наведено на рисунках 1, 2, 3, 4.

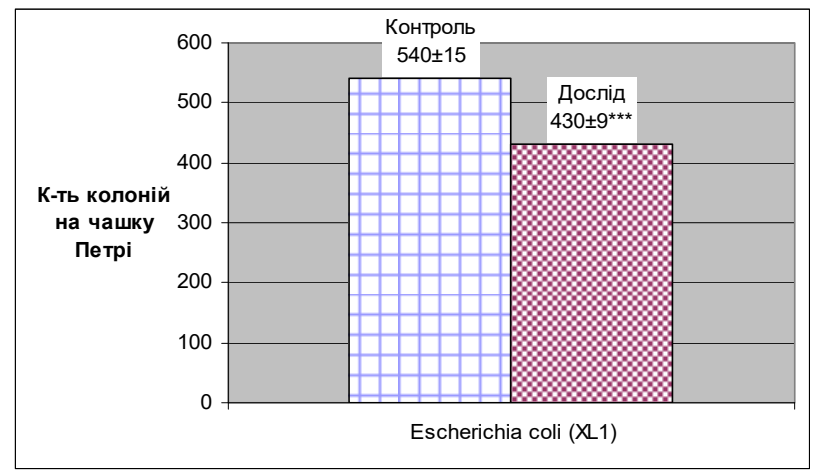

Рис. 1. Вплив 20\% екстракту Galega orientalis (Lam) на ріст чистої культури грам-негативних бактерій E. coli XL1

При вивченні антимікробної дії 20,0\% водного екстракту Galega orientalis (La) на ріст грам-негативних бактерій E.coli штаму DH 5 виявилось, що у дослідних чашках було на 117 колоній менше, ніж у контролі. У відсотковому значенні це означає на 30,0\% $(\mathrm{P}<0,001)$ гальмування росту бактерій. 


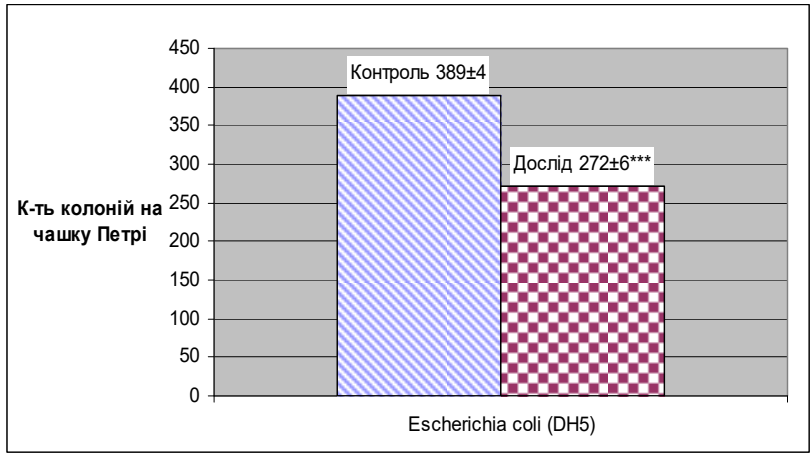

Рис. 2. Вплив 20\% екстракту Galega orientalis (Lam) на ріст чистої культури грам-негативних бактерій E.coli DH 5

Проведені мікробіологічні дослідження вказують, що дещо меншою була антибактерійна дія досліджуваного препарату на грам-позитивні бактерії M. luteus. Встановлено, що $20 \%$ водний екстракт Galega orientalis (La) пригнічує ріст даних мікроорганізмів на $12,0 \%(\mathrm{P}<0,05)$ порівняно 3 контролем.

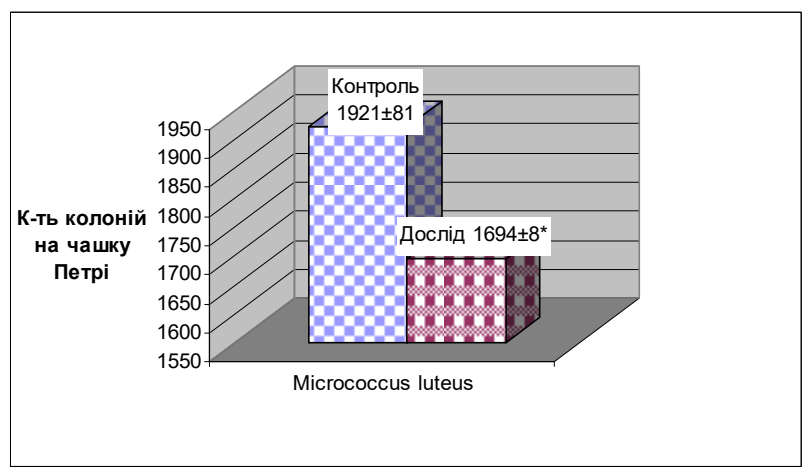

Рис. 3. Вплив 20\% екстракту Galega orientalis (Lam) на ріст чистої культури грам-позитивних бактерій M. luteus

Виявлено негативний вплив водного екстракту Galega orientalis (La) на ріст еукаріотичних мікроорганізмів - дріжджів Saccharomyces cerevisiae штаму W303 Виявлено, що у дослідних чашках кількість колоній була на 30,5\% (P < 0,01) менша порівняно 3 контролем.

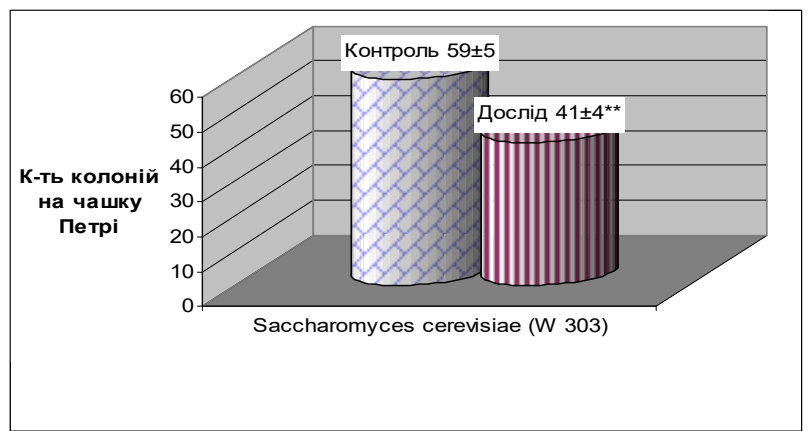

Рис. 4. Гальмівна дія 20\% екстракту Galega orientalis (Lam) на ріст чистої культури дріжджів S. cerevisiae $W 303$
Принагідно відзначити, що у всіх випадках експериментальних досліджень додавання препарату Galega orientalis (La) не змінювало морфології колоній тестованих штамів.

\section{Висновки}

Отже, отримані результати досліджень дозволяють відзначити незначну антимікробну дію 20,0\% водного екстракту Galega orientalis (La) на ріст чистих культур грам-негативних та грам-позитивних бактерій i дріжджів. Даний факт може бути використаний у харчовій промисловості, як антимікробний агент природного походження, для збереження і забезпечення мікробіологічної чистоти продуктів. Також, встановлене дає можливість припустити, що відсутність тимпанії у тварин, яким згодовували цю рослину, може бути пов'язана із гальмуванням розвитку мікроорганізмів.

Для перевірки цієї гіпотези потрібно проводити подальші комплексні дослідження. Доцільно також розширити коло тестованих культур, способи екстракцій та діапазон концентрацій досліджуваного водного препарату щодо з'ясування даної проблеми .

\section{References}

Cwalina-Ambroziak, B., \& Koc, J. (2005). Grzyby zasiedlające nadziemne organy roślin rutwicy wschodniej (Galega orientalis Lam.) uprawianej w siewie czystym i w mieszance ze stokłosą bezostną (Bromus inermis Leyss.) [Fungi colonising the aboveground parts of fodder galega (Galega orientalis Lam.) cultivated in pure sowing and mixed with smooth bromegrass (Bromus inermis Leyss.)]. Acta Agrobotanica. 58(1), 125-133. doi: 10.5586/aa.2005.018.

Darmohray L.M. (2009). Metodychni recomendaciyi shchodo vykorystannya kormiv iz (Galega orientalis (Lam) riznymy vydamy tvaryn [Methodical recommendations of using fodder of (Galega orientalis(Lam) for different kinds of animals]. Lviv (in Ukrainian).

Darmohray, L.M. (2009). Fitohimichne vyvchennya vmistu biolohichno aktyvnyh rechovyn ta testuvannya antymicrobnoi actyvnosti halehy shidnoi (Galega orientalis (Lam). Nauk. Visnyk Lvivskoho nacionalnoho universytetu veterynarnoi medycyny ta biotechnolohiy im. S.Z. Hshyzkoho. 11, 3(42), 239-242 (in Ukrainian).

Darmohray, L.M. (2010). Experimental justification for the use of nutrients and biologically active substances from food (Galega orientalis (La) different kinds of animals. - Manuscript. Doctor of Agricultural Sciences, specialty 06.02 .02 - animal nutrition and feed technology. - Lviv National University of Veterinary Medicine and Biotechnologies named after S.Z. Gzhytskyj, Lviv, 42 Lviv (in Ukrainian).

Darmohray, L.M. (2016). Analizy i metody otsinky pozhyvnosti kormiv. Navchalnyi posibnyk. Lviv (in Ukrainian).

Darmohray, L., Sedilo, G., \& Gutyj, B. (2017). Conceptual framework for the assessment of the nutritional and biological value of the plant Galega 
orientalis (LAM). Scientific Messenger of LNU of Veterinary Medicine and Biotechnologies, 19(79), 912. doi: 10.15421/nvlvet7902.

Darmohray, L.M., \& Gonchar, M.V. (2015). Bioactivity of Pure Cultures of Bacteria and Yeast in the Background Action of the Water Extract of a Plant Galega orientalis (Lam). Research \& Reviews: Journal of Veterinary Sciences. 1(1), 82-85.

Darmohray, L.M., \& Vlizlo, V.V. (2015). Doslidzennya antymicrobnyh vlastyvostey vodnoho ekstractu roslyny Galega orientalis (Lam). Naukovyy visnyk NUBiT. Kyiv. 214, 51-58 (in Ukrainian).

Egamberdieva, D., Berg, G., Lindström, K., \& Räsänen, L.A. (2010). Co-inoculation of Pseudomonas spp. with Rhizobium improves growth and symbiotic performance of foddergalega (Galega orientalis Lam.). European Journal of Soil Biology. 46(3-4), 269-272. doi: 10.1016/j.ejsobi.2010.01.005.

Hrinkevich, N.I. (1983). Himicheskiy analiz lekarstvennyh rasteniy [Chemical analysis of medicinal plants] M.: Vysshaya shkola (in Russian).
Khan, M.R., Kihara, M., \& Omoloso, A.D. (2001). Antimicrobial activity of Cassia alata. Fitoterapia. 72(5), 561-564. doi: 10.1016/S0367-326X(00)00335-X.

Sen, A., \& Batra, A. (2012). Evaluation of antimicrobial activity of different solvent extracts of medicinal plant: Melia azedarach L. International Journal of Current Pharmaceutical Research. 4(2), 67-73. Access mode: http://www.ijcpr.org/Issues/Vol4Issue2/488.pdf.

Sibanda, T., \& Okoh, A.I. (2008). In vitro antibacterial regimes of crude aqueous and acetone extracts of Garcinia kola seeds. Journal of Biological Sciences. 8(1), 149-154. doi: 10.3923/jbs.2008.149.154.

Symanowicz, B., Kalembasa, S., Jaremko, D., \& Niedbała, M. (2015). Effect of nitrogen fertilisation of Galega orientalis Lam. on the yield and content K, $\mathrm{Na}, \mathrm{Ca}$ and $\mathrm{Mg}$ in the plant and soil. Environmental Protection and Natural Resources. 26(2), 15-20. doi: 10.1515/oszn-2015-0004 